\title{
Comparison and evaluation of lupus nephritis response criteria in lupus activity indices and clinical trials
}

\author{
Kristin M Corapi ${ }^{1 *}$, Mary Anne Dooley ${ }^{2}$ and William F Pendergraft $\|^{2}$
}

\begin{abstract}
Systemic lupus erythematosus (SLE) is a systemic autoimmune disease with diverse manifestations. Although the approval of new therapies includes only one agent in 50 years, a number of promising new drugs are in development. Lupus nephritis is a dreaded complication of SLE as it is associated with significant morbidity and mortality. Advancing the treatment of lupus nephritis requires well-designed clinical trials and this can be challenging in SLE. The major obstacles involve identifying the correct population of patients to enroll and ensuring that a clinically appropriate and patient-centered endpoint is being measured. In this review, we will first discuss the clinical utility of endpoints chosen to represent lupus nephritis in global disease activity scales. Second, we will review completed and active trials focused on lupus nephritis and discuss the endpoints chosen. There are many important lessons to be learned from existing assessment tools and clinical trials. Reviewing these points will help ensure that future efforts will yield meaningful disease activity measures and well-designed clinical trials to advance our understanding of lupus management.
\end{abstract}

\section{Introduction}

Kidney involvement in lupus, particularly in high-risk populations, can lead to end-stage kidney disease (ESKD). Carefully designed trials to identify strategies to calm flares of lupus nephritis (LN) and identify drug regimens to maintain remission are essential. Historically, high-dose corticosteroids were the mainstay of treatment for $\mathrm{LN}$, and not until the mid-1980s was cyclophosphamide found

\footnotetext{
* Correspondence: kcorapi@partners.org

'Division of Nephrology, Department of Medicine, Massachusetts General Hospital, 55 Fruit St., Boston, MA 02114, USA

Full list of author information is available at the end of the article
}

to prolong renal survival [1]. Subsequently, glucocorticoid therapy and cyclophosphamide became the standard induction regimen. Research has focused on identifying regimens that allow shorter treatment courses, lower glucocorticoid doses, and less toxicity [2]. No therapies are approved for the treatment of systemic lupus erythematosus (SLE) aside from aspirin, prednisone, hydroxychloroquine, and belimumab. In this review, we will focus on previous and ongoing trials specifically related to the treatment of LN.

Critical analysis of completed LN clinical trials will allow us to design effective and meaningful clinical trials in the future. A well-designed study requires precise inclusion and exclusion criteria, guidelines on standardized steroid dosing, and carefully chosen endpoints. SLE is a systemic disease, and although a particular treatment might benefit kidney involvement, an awareness of the impact on disease activity in other organs is essential. Numerous global disease activity indices have been developed to quantify disease activity. In this review, we will evaluate the renal response criteria within the most frequently used disease activity indices and determine whether they can be translated easily into clinical practice. We will also evaluate the clinical utility of endpoints in past and current clinical trials in LN.

\section{Lupus nephritis disease burden}

SLE is a complex and potentially life-threatening autoimmune disease. Kidney involvement, which affects the majority of patients, remains the most significant cause of morbid and mortal complications [3,4]. The incidence of ESKD and the overall mortality among patients with LN have not improved in populations studied in London, Toronto, and the United States [5]. In fact, United States Renal Data System data analysis of trends in outcomes of ESKD due to incident LN from 1995 to 2006 revealed that the incidence of ESKD is increasing [6]. In addition, renal flares may be an independent predictor of incident and 
progressive chronic kidney disease (CKD) [7]. Patients with lower socioeconomic status have an even worse prognosis [8-10]. Advances in identification and characterization of etiologic and pathogenic mechanisms underlying LN have not led to more effective treatments for $\mathrm{LN}$, despite advances in the treatment of important co-morbidities, including diabetes, hyperlipidemia, and hypertension $[4,11,12]$. A sobering fact remains: up to $70 \%$ of patients with LN are resistant to current immunosuppressive regimens [13]. Filling this gap is paramount for the prevention, treatment, and cure of LN. The current clinical management of patients with $\mathrm{LN}$ remains limited to the use of non-specific cytotoxic drugs despite the advent of numerous potential biologic agents [3].

\section{Surveillance of lupus nephritis in clinical nephrology}

Kidney involvement in SLE is heralded by either the presence of proteinuria ( $>0.5 \mathrm{~g}$ /day), active urinary sediment (with red blood cell, granular, tubular and/or mixed casts), or an unexplained rise in serum creatinine. A kidney biopsy is the gold standard to diagnose LN as it provides information regarding the pattern and severity of renal involvement as well as the stage, activity, and chronicity. These are all important considerations influencing treatment decisions [14]. Immunosuppressant medication is used to halt kidney injury when proliferative disease is found at biopsy. The pathologic classification of LN has evolved-the most recent International Society of Nephrology/Renal Pathology Society 2003 classification of LN guidelines was published in 2004-in an effort to better capture the spectrum of kidney involvement [15].

Nephrologists monitor LN activity by trending the estimated glomerular filtration rate (eGFR) and proteinuria and by conducting an interval examination of the urine sediment. There are several techniques used to determine eGFR: the Modification of Diet in Renal Disease, Cockcroft-Gault, or CKD-epi equations. There is no consensus as to which estimating equation is preferred, and head-to-head comparisons are inconclusive. Each estimating equation has advantages and disadvantages in certain clinical settings. Another option is to measure the GFR by using a 24-hour urine collection; however, this is burdensome for the patient and open to technique problems such as under-collection [15-17].

Just as no consensus exists to the best method of determining GFR, there is more than one approach to determining the quantity of proteinuria. Some centers use spot urine samples to calculate the urine protein-tocreatinine ratio, whereas others opt for a 24-hour or timed sample to quantify protein excretion. Recent work suggests that the spot protein-to-creatinine ratio may be inaccurate in the assessment of the degree of proteinuria in LN as compared with other forms of chronic glomerular disease; however, prospective studies are needed to confirm and validate this finding [16].

Finally, serial urinalyses to detect hematuria and reexamination of the sediment to look for cellular or mixed casts also help the treating physician determine whether active kidney involvement persists. An assessment of eGFR, proteinuria, and urinary sediment is essential to the early detection of LN flares and to allow prompt intervention. A standardized approach to each facet of $\mathrm{LN}$ surveillance is needed to allow comparisons of treatment strategies.

\section{Renal subscales in systemic lupus erythematosus disease activity scales}

Given the systemic nature of SLE, it is important to monitor overall lupus disease activity when instituting therapy. A treatment may benefit one organ system at the expense of worsening symptoms in another. Previous guidance from the US Food and Drug Administration (FDA) suggests that clinical trials in SLE be designed with a primary endpoint of overall disease activity [17]. Table 1 summarizes the renal subscales of some of the commonly used lupus activity instruments [18]. There are additional disease activity scales, but not all include a renal subscale $[19,20]$. In general, the disease activity scales include various SLE manifestations and the clinician is asked to ascertain the presence or absence of each by using the definitions supplied and then to establish the disease activity score.

Disease activity indices that include surveillance parameters routinely assessed in clinical practice are more easily translated into clinical use as the physician already has the necessary data. eGFR and proteinuria are both objective and routinely measured by treating physicians. As discussed earlier, recent evidence suggests that a 24hour collection is more reliable than a spot urine sample to quantify proteinuria in LN, albeit much more difficult for patients to perform [16]. eGFR can be estimated from one of many equations, but prospective work is needed to determine the most accurate and reliable equation in $\mathrm{LN}$. These two measures of kidney function are routinely performed as part of clinical care and are easy to interpret; thus, their inclusion as endpoints in renal subscales makes for a seamless transition from a research setting to the clinic. We feel strongly that any assessment of LN activity should include a measure of both proteinuria and glomerular filtration.

Although the urine sediment gives important clues to the presence of ongoing nephritis, slide preparation and interpretation are operator-dependent. Benign kidney disease such as mesangial proliferation can be associated with red blood cell (RBC) casts yet would not require immunosuppressant treatment, whereas proliferative disease 
Table 1 Renal response criteria in global systemic lupus erythematosus scoring tools

\begin{tabular}{|c|c|c|c|c|}
\hline Scale & Time period & Scoring & Renal response criteria & Strengths and criticisms [18] \\
\hline \multicolumn{5}{|l|}{ Disease activity } \\
\hline \multirow[t]{4}{*}{ SLEDAI-2K [45] } & \multirow[t]{4}{*}{10 days } & \multirow{4}{*}{$\begin{array}{l}\text { - The presence of each of the } \\
\text { renal manifestations adds } 4 \\
\text { points to patient's total score. }\end{array}$} & $\begin{array}{l}\text { - Urinary casts (heme-granular } \\
\text { or RBC) }\end{array}$ & $\begin{array}{l}\checkmark \text { Validated for clinical and } \\
\text { research use }\end{array}$ \\
\hline & & & - Hematuria (>5 RBCs/hpf) & $\begin{array}{l}\text { - Does not capture } \\
\text { improving or worsening }\end{array}$ \\
\hline & & & $\begin{array}{l}\text { - Proteinuria ( }>0.5 \mathrm{~g} / 24 \text { hours, } \\
\text { new onset or increase of }>0.5 \\
\text { g/24 hours) }\end{array}$ & $\begin{array}{l}\text { - Must wait for labs to } \\
\text { score }\end{array}$ \\
\hline & & & $\begin{array}{l}\text { • Pyuria (>5 WBCs/hpf, } \\
\text { excluding infection) }\end{array}$ & \\
\hline \multirow[t]{19}{*}{ BILAG [46] } & \multirow[t]{19}{*}{ One month } & $\begin{array}{l}\cdot \text { Category A (severe disease) = } \\
\geq 2 \text { of the following: }\end{array}$ & - Blood pressure & $\begin{array}{l}\checkmark \text { Incorporates an element of } \\
\text { change }\end{array}$ \\
\hline & & 1. Proteinuria, defined as & - Accelerated hypertension? & $\checkmark$ Sensitive to small changes \\
\hline & & $\begin{array}{l}\text { (a) urinary dipstick increased } \\
\text { by } 2 \text { or more levels }\end{array}$ & $\begin{array}{l}\text { - Proteinuria (on either dipstick } \\
\text { or } 24 \text {-hour collection) }\end{array}$ & $\begin{array}{l}\checkmark \text { Can identify if disease } \\
\text { improving, stable, or worse }\end{array}$ \\
\hline & & $\begin{array}{l}\text { (b) } 24 \text { urinary protein rising } \\
\text { from }<0.20 \text { to }>1 \mathrm{~g}\end{array}$ & o $>1 \mathrm{~g} / 24$ hours? & $\begin{array}{l} \pm \text { scoring can be complex } \\
\text { (computer program available) }\end{array}$ \\
\hline & & $\begin{array}{l}\text { (c) } 24 \text { hour urinary protein } \\
\text { rising from }>1 \mathrm{~g} \text { by } 100 \%\end{array}$ & o UPCR >100 mg/mmol? & \\
\hline & & $\begin{array}{l}\text { (d) newly documented } \\
\text { proteinuria of }>1 \mathrm{~g}\end{array}$ & - Nephrotic syndrome? & $\circ$ Requires formal training \\
\hline & & 2. Accelerated hypertension & - Creatinine & $\circ$ Developed for research \\
\hline & & $\begin{array}{l}\text { 3. Deteriorating kidney function, } \\
\text { defined as }\end{array}$ & - Creatinine clearance/GFR & $\begin{array}{l}\text { - Up to } 50 \text { minutes to } \\
\text { complete }\end{array}$ \\
\hline & & $\begin{array}{l}\text { (a) plasma creatinine }>130 \\
\mu m o l / L \text { and having risen to } \\
>130 \%\end{array}$ & $\begin{array}{l}\text { - Active urinary sediment (>5 } \\
\text { WBCs/hfp, }>5 \text { RBCs/hpf, or } \\
\text { RBC casts) }\end{array}$ & $\begin{array}{l}\text { - Must wait for labs to } \\
\text { score }\end{array}$ \\
\hline & & $\begin{array}{l}\text { (b) creatinine clearance fallen } \\
\text { to }<67 \% \text { of previous value }\end{array}$ & \multirow{10}{*}{$\begin{array}{l}\text { - Histologic evidence of } \\
\text { nephritis in the previous } 3 \\
\text { months? (excludes sclerosis) }\end{array}$} & \\
\hline & & $\begin{array}{l}\text { (c) creatinine clearance }<50 \\
\mathrm{~mL} / \mathrm{min} \text {, and last time was } \\
>50 \mathrm{~mL} / \mathrm{min} \text { or was not } \\
\text { measured }\end{array}$ & & \\
\hline & & 4. Active urinary sediment & & \\
\hline & & $\begin{array}{l}\text { 5. Histological evidence of active } \\
\text { nephritis }\end{array}$ & & \\
\hline & & $\begin{array}{l}\text { - Category B (moderate disease) } \\
=\text { one of the following: }\end{array}$ & & \\
\hline & & $\begin{array}{l}\text { 1. Any one of the category A } \\
\text { criteria above }\end{array}$ & & \\
\hline & & 2. Proteinuria & & \\
\hline & & $\begin{array}{l}\text { (a) urinary dipstick which has } \\
\text { risen by } 1+\text { or }>2+\end{array}$ & & \\
\hline & & $\begin{array}{l}\text { (b) 24-hour urinary protein } \\
\text { rising from }>1 \text { g by }>50 \% \\
\text { but }<100 \%\end{array}$ & & \\
\hline & & $\begin{array}{l}\text { 3. Plasma creatinine }>130 \mu \mathrm{mol} / \mathrm{L} \\
\text { and having risen } 115 \%\end{array}$ & & \\
\hline \multirow[t]{2}{*}{ ECLAM } & \multirow[t]{2}{*}{ One month } & $\begin{array}{l}\text { - } 0.5 \text { points for each renal criteria } \\
\text { present }\end{array}$ & - Proteinuria $\geq 500 \mathrm{mg} /$ day & $\begin{array}{l}\checkmark \text { Derived from a large } \\
\text { number of real patients and } \\
\text { standardized data }\end{array}$ \\
\hline & & $\begin{array}{l}\text { - } 2 \text { extra points added if only } \\
\text { kidney involvement }\end{array}$ & $\begin{array}{l}\text { - Urinary casts (RBCs, } \\
\text { hemoglobin, granular, tubular, } \\
\text { or mixed) }\end{array}$ & $\checkmark$ Easy to administer and scor \\
\hline
\end{tabular}


Table 1 Renal response criteria in global systemic lupus erythematosus scoring tools (Continued)

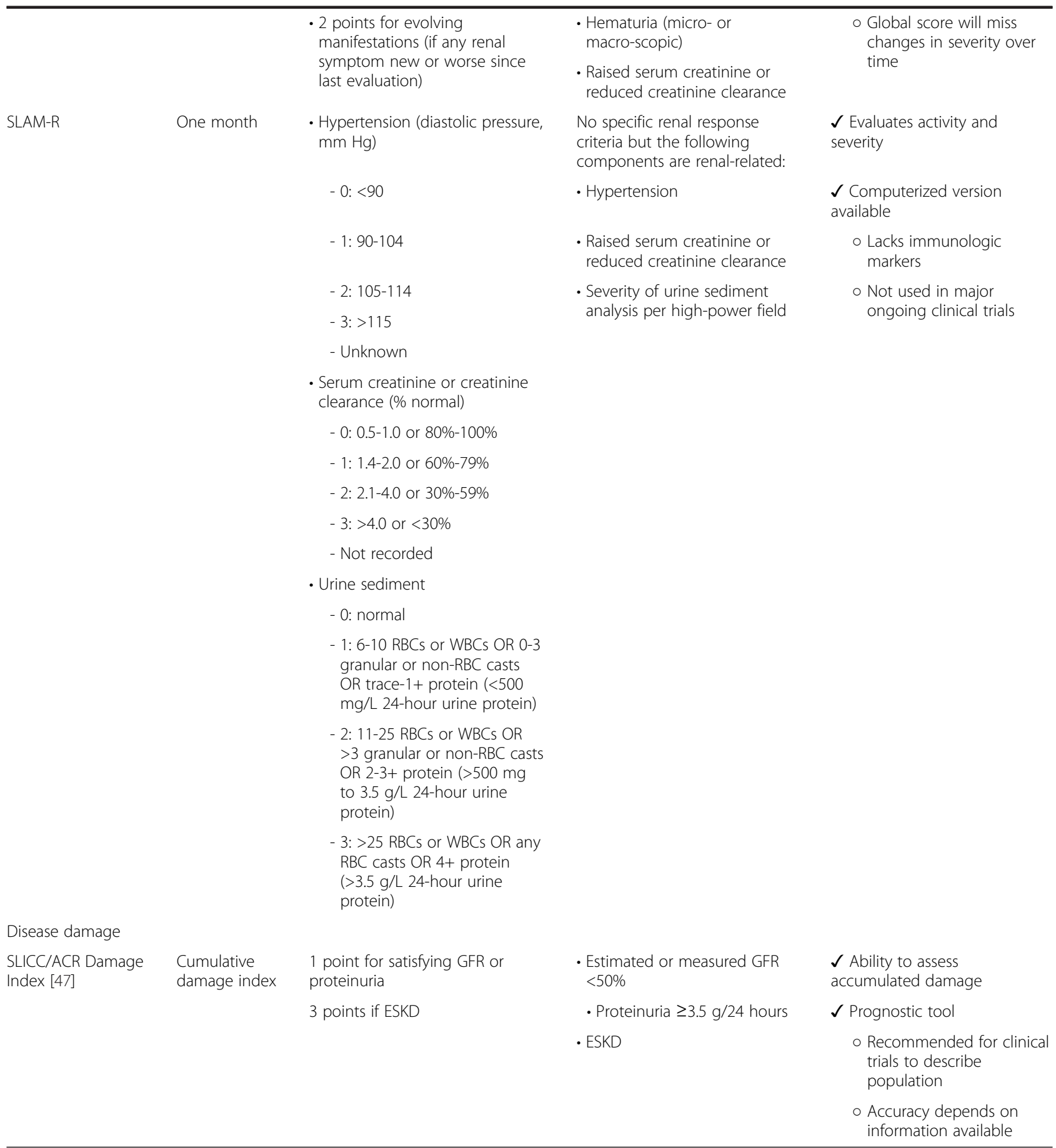

BILAG, British Isles Lupus Assessment Group Index; ECLAM, European Consensus Lupus Activity Measurement; ESKD, end-stage kidney disease; GFR, glomerular filtration rate; hpf, high-power field; RBC, red blood cell; SLAM-R, Systemic Lupus Activity measure-revised; SLEDAI-2 K, systemic lupus erythematosus Disease activity index- 2K; SLICC/ACR, Systemic Lupus International Collaborating Clinics/American College of Rheumatology; UPCR, urinary protein-to-creatinine ratio; WBC, white blood cell.

can be seen in the setting of a bland sediment [21]. Evaluation of the urine sediment alone is insufficient to determine whether kidney disease is present. A better approach is demonstrated in the British Isles Lupus Assessment
Group (BILAG), European Consensus Lupus Activity Measure, and Systemic Lupus Activity Measure-Revised renal subscales, which consider the urine sediment in conjunction with eGFR and proteinuria. As pointed out by 
the American College of Rheumatology, before treatment decisions are placed solely on the urine sediment, reproducibility needs to be demonstrated [21].

The optimal renal subscale is one that is sensitive to change, whether improvement or deterioration. Both the magnitude and the presence of change are notable. This is best captured with serial measurement; therefore, development of a scale that is easy to administer and score is preferred. The requirement for formal training or complicated scoring will impair utility in clinical use.

\section{Renal endpoints in clinical trials of lupus nephritis: past and present Completed trials}

Glucocorticoids and intermittent intravenous cyclophosphamide (IVC) have long been considered the standard induction agents to treat LN. Steinberg and Decker [22] reported the success of cyclophosphamide when compared with azathioprine (AZA) or placebo for inducing remission over the course of a 10 -week period in a randomized trial of 38 patients during the mid-1970s. Patients were evaluated with respect to change in creatinine clearance, proteinuria, and urine sediment [22]. Amongst the treatment regimens studied by Austin and colleagues [1], the authors reported reduced rates of ESKD in a sample of mostly Caucasian patients who received IVC and glucocorticoids when compared to glucocorticoid monotherapy. LN has remained a research focus in an effort to identify more effective and less toxic treatment strategies. Table 2 includes a summary of important randomized controlled trials for the treatment of LN from the last 15 years. Although these studies have influenced the care of patients, none has led to FDA approval for an agent in the treatment of LN. Studies have varied in inclusion of patients by race and ethnicity, geographic region, size, duration of follow-up, and chosen primary and secondary endpoints.

Studies can be divided into two types: studies of induction or maintenance of remission. An induction trial compares two treatments with respect to efficacy in achieving disease remission, whereas maintenance studies compare therapies with respect to limiting the frequency of flares [23]. Common endpoints in an induction trial are measures of disease activity. As demonstrated in Table 2, there is no standardized definition of 'complete remission'. The definitions for remission of proteinuria vary from less than $0.3 \mathrm{~g} /$ day [24] to less than $3 \mathrm{~g} /$ day [25] to an improvement of more than $50 \%$ [25]. In studies that have included a measurement of eGFR, definitions of remission differ from comparisons made to the baseline value [24-26] versus comparisons made to normal values $[27,28]$. Trials of maintenance therapy focus on 'treatment failure' as the primary endpoint. These studies tend to be of longer duration, which affords them the opportunity to invoke hard endpoints such as patient survival, the need for renal replacement therapy, the occurrence of flare, or progressive kidney disease $[29,30]$.

The trial that assessed efficacy and safety of adding abatacept to mycophenolate mofetil (MMF) highlights the need to define endpoints carefully [26]. The definition of 'complete response' chosen by those investigators was likely too restrictive as it included a composite measure that required maintenance of eGFR, minimal proteinuria, and inactive urinary sediment over the 52-week treatment period. This may be one reason why the response rate among all participants was much lower than expected [31,32].

It is unethical to deny study participants effective treatment, and therefore investigators must decide on a steroid dosing strategy in the trial design. As the examples in Table 2 illustrate, defining the dose and type of glucocorticoid to be used for induction is important but not standardized across trials. In addition, clinical trials must provide instructions for a taper and specify how to treat a flare to avoid confounding due to different cumulative steroid exposure between groups. Clear guidance on the use of medications, especially non-steroidal anti-inflammatory drugs (NSAIDs), angiotensin-converting enzyme inhibitors, or angiotensin receptor blockers, is also an essential component of trial design for LN.

The studies done to determine efficacy of MMF for remission of LN illustrate the distinction between superiority and non-inferiority trials. The studies by Chan and colleagues [24] and Ginzler and colleagues [27] were noninferiority trials. Based on the success of MMF in these trials, the Aspreva Lupus Management Study Group trial was designed as a superiority trial, and numerous sites around the globe participated [25,31]. Comparable rates of patients responded to treatment in the two arms; however, MMF failed to demonstrate superiority, and therefore this was considered a negative trial.

\section{Ongoing clinical trials}

Four major clinical trials to attempt to improve treatment of LN have recently been completed or are under way (Table 3). These include the following:

1. The ACCESS trial (Abatacept and Cyclophosphamide Combination: Efficacy and Safety Study), sponsored by the National Institute of Allergy and Infectious Diseases through the Immune Tolerance Network, assesses the efficacy of abatacept (a fusion protein composed of the Fc region of IgG1 fused to the extracellular domain of CTLA-4 that prevents T-cell activation) versus placebo in the treatment of proliferative LN (class III or IV with/without class V) with background therapy of Eurolupus IVC (500 mg 
Table 2 An overview of landmark randomized controlled trials of lupus nephritis treatments published since 2000

\begin{tabular}{|c|c|c|c|c|c|c|c|}
\hline Reference & Study design & $\begin{array}{l}\text { Number of } \\
\text { patients }\end{array}$ & $\begin{array}{l}\text { Follow-up, } \\
\text { months }\end{array}$ & Intervention & Steroids & Endpoint & Conclusion \\
\hline \multicolumn{8}{|l|}{ Induction } \\
\hline \multirow[t]{3}{*}{$\begin{array}{l}\text { Chan et al. [24] } \\
\text { (2000) }\end{array}$} & \multirow[t]{3}{*}{$\begin{array}{l}\text { Randomized, single- } \\
\text { center study }\end{array}$} & \multirow[t]{3}{*}{42} & \multirow[t]{3}{*}{12} & \multirow[t]{3}{*}{$\begin{array}{l}\text { MMF }(1 \mathrm{~g} \mathrm{BID}) \text { versus CYC } \\
(2.5 \mathrm{mg} / \mathrm{kg})\end{array}$} & \multirow[t]{3}{*}{$\begin{array}{l}\text { Prednisolone } 0.8 \mathrm{mg} / \mathrm{kg} \\
\text { followed by taper, } \\
\text { maintenance dose } 10 \\
\text { mg/day }\end{array}$} & $\begin{array}{l}\text { - Complete remission }=U \mathrm{upr}<0.3 \\
\text { g/day, with normal sediment, } \\
\text { normal albumin, and } \mathrm{SCr} \text { and } \mathrm{CrCl} \\
\leq 15 \% \text { above baseline }\end{array}$ & \multirow[t]{3}{*}{$\begin{array}{l}\text { Rate of remission similar } \\
\text { between groups }\end{array}$} \\
\hline & & & & & & $\begin{array}{l}\text { - Partial remission }=U p r \geq 0.3 \text { and } \\
<2.9 \mathrm{~g} / \text { day, albumin } \geq 3.0 \mathrm{~g} / \mathrm{dL} \text {, and } \\
\text { stable kidney function }\end{array}$ & \\
\hline & & & & & & $\begin{array}{l}\text { - Treatment failure }=U \mathrm{pr} \geq 3.0 \mathrm{~g} / \text { day, } \\
\text { or Upr }<3.0 \text { with serum albumin } \\
<3.0 \mathrm{~g} / \mathrm{dL} \text {, SCr that has increased } \\
>0.6 \mathrm{mg} / \mathrm{dL} \text {, or } \mathrm{CrCl}>15 \% \text { above } \\
\text { baseline }\end{array}$ & \\
\hline \multirow[t]{5}{*}{$\begin{array}{l}\text { Houssiau et al. [48] } \\
\text { (2002) }\end{array}$} & \multirow[t]{5}{*}{$\begin{array}{l}\text { Randomized non- } \\
\text { inferiority, multicenter }\end{array}$} & \multirow[t]{5}{*}{90} & \multirow[t]{5}{*}{41} & \multirow{5}{*}{$\begin{array}{l}\text { High CYC (monthly } \\
\text { pulses, dose adjusted } \\
\text { based on WBC) versus } \\
\text { low-dose CYC (500 mg } \\
\text { every } 2 \text { weeks) }\end{array}$} & \multirow{5}{*}{$\begin{array}{l}\text { Methylpred three times } \\
\text { followed by prednisolone } \\
\text { taper, maintenance dose } \\
5 \text { to } 7.5 \mathrm{mg} / \text { day }\end{array}$} & $\begin{array}{l}\text { - Treatment failure = one of the } \\
\text { following: }\end{array}$ & \multirow[t]{5}{*}{$\begin{array}{l}\text { Similar treatment failure } \\
\text { rates between groups }\end{array}$} \\
\hline & & & & & & $\begin{array}{l}\text { - Absence of a primary response } \\
\text { after } 6 \text { months }\end{array}$ & \\
\hline & & & & & & $\begin{array}{l}\text { Occurrence of glucocorticoid } \\
\text { resistant flare }\end{array}$ & \\
\hline & & & & & & - Doubling of serum creatinine & \\
\hline & & & & & & $\begin{array}{l}\text { - Lack of improvement in kidney } \\
\text { function if dysfunction present } \\
\text { at baseline }\end{array}$ & \\
\hline $\begin{array}{l}\text { Ginzler et al. [27] } \\
\text { (2005) }\end{array}$ & $\begin{array}{l}\text { Randomized, open-label, } \\
\text { non-inferiority }\end{array}$ & 140 & 6 & $\begin{array}{l}\text { Oral MMF daily (up to } 3 \\
\text { g/day) versus monthly } \\
\text { CYC (up to } 1.0 \mathrm{~g} / \mathrm{m}^{2} \text { ) }\end{array}$ & $\begin{array}{l}\text { Glucocorticoids } 1 \mathrm{mg} / \mathrm{kg} \\
\text { per day followed by taper } \\
\text { at clinician's discretion }\end{array}$ & $\begin{array}{l}\text { - Complete remission: return to } \\
\text { within } 10 \% \text { of normal values for } \\
\text { creatinine, proteinuria, and urine } \\
\text { sediment }\end{array}$ & $\begin{array}{l}\text { MMF was superior to CYC } \\
\text { for induction }\end{array}$ \\
\hline \multirow{4}{*}{$\begin{array}{l}\text { Appel et al. [25] } \\
\text { (2009) }\end{array}$} & \multirow{4}{*}{$\begin{array}{l}\text { Randomized controlled, } \\
\text { superiority trial }\end{array}$} & \multirow[t]{4}{*}{370} & \multirow[t]{4}{*}{6} & \multirow{4}{*}{$\begin{array}{l}\text { MMF (3 g/day) versus IV } \\
\left.\text { CYC (0.5 to } 1.0 \mathrm{~g} / \mathrm{m}^{2}\right)\end{array}$} & \multirow{4}{*}{$\begin{array}{l}\text { Glucocorticoids } 60 \mathrm{mg} \\
\text { followed by taper }\end{array}$} & - Response defined as: & \multirow{4}{*}{$\begin{array}{l}\text { Overall response rate the } \\
\text { same in MMF and CYC } \\
\text { groups }\end{array}$} \\
\hline & & & & & & $\begin{array}{l}\circ \text { Decrease in UPCR to }<3 \text { from a } \\
\text { 24-hour collection in patients } \\
\text { with baseline UPCR }>3\end{array}$ & \\
\hline & & & & & & $\begin{array}{l}\text { - Decrease in UPCR of }>50 \% \text { if } \\
\text { sub-nephrotic at baseline }\end{array}$ & \\
\hline & & & & & & $\begin{array}{l}\text { Stabilization }( \pm 25 \%) \text { or } \\
\text { improvement in serum } \\
\text { creatinine }\end{array}$ & \\
\hline \multirow[t]{2}{*}{$\begin{array}{l}\text { Rovin et al. [28] } \\
\text { (2012) }\end{array}$} & \multirow[t]{2}{*}{$\begin{array}{l}\text { Randomized, placebo- } \\
\text { controlled, multicenter }\end{array}$} & \multirow[t]{2}{*}{144} & \multirow[t]{2}{*}{12} & \multirow[t]{2}{*}{$\begin{array}{l}\text { Addition of ritxumab } \\
\text { versus placebo to MMF } \\
\text { and steroids }\end{array}$} & \multirow[t]{2}{*}{$\begin{array}{l}\text { Methylpred } 1 \mathrm{~g} \text { two times } \\
\text { peri-study drug doses }\end{array}$} & $\begin{array}{l}\text { - Complete renal response }=\text { normal } \\
\text { SCr (if abnormal at baseline), } \\
\text { inactive sediment, or UPCR }<0.5\end{array}$ & \multirow[t]{2}{*}{$\begin{array}{l}\text { Response rates similar } \\
\text { among groups }\end{array}$} \\
\hline & & & & & & $\begin{array}{l}\text { - Partial renal response }=\mathrm{SCr} \leq 115 \% \\
\text { of baseline, } \mathrm{RBCS} / \mathrm{hpf} \leq 50 \% \text { above }\end{array}$ & \\
\hline
\end{tabular}




\begin{tabular}{|c|c|c|c|c|c|c|c|}
\hline & & & & & & $\begin{array}{l}\text { baseline, no RBC casts, and at least } \\
50 \% \text { decrease in UPCR or to }<1.0 \text { (if } \\
\text { baseline was } \leq 3.0 \text { ) or to } \leq 3.0 \text { (if } \\
\text { baseline was }>3.0 \text { ) }\end{array}$ & \\
\hline & & & & & & $\begin{array}{l}\text { - No response }=\text { did not meet } \\
\text { criteria for complete or partial } \\
\text { response, terminated study early, or } \\
\text { missing data limited ability to } \\
\text { assess }\end{array}$ & \\
\hline $\begin{array}{l}\text { Furie et al. [26] } \\
\text { (2014) }\end{array}$ & $\begin{array}{l}\text { Randomized, phase }\|/\| I \| \\
\text { multicenter, double-blind } \\
\text { study }\end{array}$ & 298 & 12 & $\begin{array}{l}\text { Standard dose abatacept, } \\
\text { high-dose abatacept, or } \\
\text { placebo }\end{array}$ & $\begin{array}{l}\text { Protocol defined steroid } \\
\text { (and MMF) dosing }\end{array}$ & $\begin{array}{l}\text { - Complete response }=\text { eGFR } \geq 90 \% \\
\text { of screening or pre-flare value, } \\
\text { UPCR }<0.26 \text {, inactive urinary } \\
\text { sediment }\end{array}$ & $\begin{array}{l}\text { Time to achievement of } \\
\text { complete response was } \\
\text { similar in all arms. }\end{array}$ \\
\hline \multirow[t]{5}{*}{$\begin{array}{l}\text { ACCESS trial group, } \\
2014 \text { [33] }\end{array}$} & \multirow[t]{5}{*}{$\begin{array}{l}\text { Randomized double } \\
\text { blind, double-blind, } \\
\text { placebo-controlled }\end{array}$} & \multirow[t]{5}{*}{134} & \multirow[t]{5}{*}{$\begin{array}{l}6 \text { and } 12 \\
\text { weeks }\end{array}$} & \multirow[t]{5}{*}{$\begin{array}{l}\text { Euro-Lupus CYC with } \\
\text { abatacept versus placebo }\end{array}$} & \multirow[t]{5}{*}{$\begin{array}{l}\text { Methyl pred x3 followed } \\
\text { by taper }\end{array}$} & $\begin{array}{l}\text { Proportion of subjects achieving } \\
\text { complete response at } 24 \text { weeks } \\
\text { defined as: }\end{array}$ & \multirow[t]{5}{*}{$\begin{array}{l}\text { No difference with } \\
\text { abatacept }\end{array}$} \\
\hline & & & & & & $\begin{array}{l}\text { - Kidney function: stable or improved } \\
\text { eGFR }\end{array}$ & \\
\hline & & & & & & - Proteinuria: UPCR $<0.5$ & \\
\hline & & & & & & - Urine sediment: not included & \\
\hline & & & & & & $\begin{array}{l}\text { - Corticosteroid dose: tapered to } \leq 10 \\
\text { mg daily }\end{array}$ & \\
\hline \multicolumn{8}{|l|}{ Maintenance } \\
\hline \multirow{2}{*}{$\begin{array}{l}\text { Contreras et al. } \\
\text { [29] (2004) }\end{array}$} & \multirow{2}{*}{$\begin{array}{l}\text { Single-center, randomized } \\
\text { open-label trial }\end{array}$} & \multirow[t]{2}{*}{60} & \multirow[t]{2}{*}{72} & \multirow{2}{*}{$\begin{array}{l}\text { IV CYC ( } 0.5 \text { to } 1.0 \mathrm{~g} / \mathrm{m}^{2} \\
\text { every } 3 \text { months) or AZA } 1 \\
\text { to } 3 \mathrm{mg} / \mathrm{kg} \text { per day or } \\
\text { MMF ( } 500 \text { to } 3,000 \mathrm{mg} / \\
\text { day) }\end{array}$} & \multirow{2}{*}{$\begin{array}{l}\text { Glucocorticoids up to } 0.5 \\
\mathrm{mg} / \mathrm{kg} \text { per day }\end{array}$} & - Patient survival & \multirow{2}{*}{$\begin{array}{l}\text { Patient survival was } \\
\text { significantly better in AZA } \\
\text { compared with CYC, and } \\
\text { renal survival was similar } \\
\text { in all groups. }\end{array}$} \\
\hline & & & & & & $\begin{array}{l}\text { - Renal survival, defined as sustained } \\
\text { increase in SCr to at least two times } \\
\text { the lowest level achieved during } \\
\text { induction, need for RRT or } \\
\text { transplant }\end{array}$ & \\
\hline $\begin{array}{l}\text { Houssiau et al. } \\
\text { [49] (2010) }\end{array}$ & Randomized trial & 105 & 48 & $\begin{array}{l}\text { AZA (target } 2 \mathrm{mg} / \mathrm{kg} \text { per } \\
\text { day) or MMF (target } 2 \mathrm{~g} / \\
\text { day) }\end{array}$ & $\begin{array}{l}\text { Methylpred three times } \\
\text { followed by taper }\end{array}$ & $\begin{array}{l}\text { - Time to renal flare }=\text { nephrotic } \\
\text { syndrome, } \geq 33 \% \text { increase in serum } \\
\text { creatinine within } 1 \text { month, } \\
\text { threefold increase in } 24 \text {-hour } \\
\text { proteinuria with hematuria, } \geq 33 \% \\
\text { reduction in C3 within } 3 \text { months }\end{array}$ & $\begin{array}{l}\text { Fewer flares with AZA but } \\
\text { failed to show superiority }\end{array}$ \\
\hline $\begin{array}{l}\text { Dooley et al. } \\
\text { [30] (2011) }\end{array}$ & $\begin{array}{l}\text { Randomized double- } \\
\text { blind, double-dummy, } \\
\text { multicenter }\end{array}$ & 227 & 36 & $\begin{array}{l}\text { MMF (1 g BID) versus } \\
\text { AZA (2 mg/kg daily) }\end{array}$ & $\begin{array}{l}\text { Glucocorticoids } 10 \text { mg/ } \\
\text { day }\end{array}$ & $\begin{array}{l}\text { - Time to treatment failure }=\text { time } \\
\text { until the first event (death, ESKD, } \\
\text { doubling of } \mathrm{SCr} \text {, renal flare, or need } \\
\text { for rescue therapy) }\end{array}$ & MMF superior to AZA \\
\hline
\end{tabular}

ACCESS, Abatacept and Cyclophosphamide Combination: Efficacy and Safety Study; AZA, azathioprine; BID, twice a day; CrCl, creatinine clearance; CYC, cystatin C; eGFR, estimated glomerular filtration rate; ESKD, end-stage kidney disease; hpf, high-power field; IV, intravenous; Methylpred, methylprednisolone; MMF, mycophenolate mofetil; RBC, red blood cell; RRT, renal replacement therapy; SCr, serum creatinine; UPCR, urinary protein-to-creatinine ratio; Upr, urinary protein excretion; WBC, white blood cell. 
Table 3 An overview of major randomized controlled trials of lupus nephritis treatments currently in progress and their response criteria

\begin{tabular}{|c|c|c|c|c|c|c|c|c|c|c|c|}
\hline $\begin{array}{l}\text { ClinicalTrials. } \\
\text { gov identifier }\end{array}$ & Sponsor & $\begin{array}{l}\text { Study } \\
\text { name }\end{array}$ & Study design & $\begin{array}{l}\text { Lupus } \\
\text { nephritis } \\
\text { class }\end{array}$ & Intervention & $\begin{array}{l}\text { Background } \\
\text { therapy }\end{array}$ & Primary outcome & $\begin{array}{l}\text { Patient } \\
\text { enrollment } \\
\text { goal, } \\
\text { number }\end{array}$ & $\begin{array}{l}\text { Sites, } \\
\text { number }\end{array}$ & $\begin{array}{l}\text { International } \\
\text { or US only }\end{array}$ & $\begin{array}{l}\text { Estimated } \\
\text { completion } \\
\text { date }\end{array}$ \\
\hline \multirow[t]{5}{*}{ NCT01714817 } & \multirow[t]{5}{*}{$\begin{array}{l}\text { Bristol-Myers } \\
\text { Squibb }\end{array}$} & \multirow[t]{5}{*}{ ALLURE } & \multirow[t]{5}{*}{$\begin{array}{l}\text { Phase 3, } \\
\text { randomized, } \\
\text { double-blind, } \\
\text { placebo- } \\
\text { controlled }\end{array}$} & \multirow[t]{5}{*}{ III or IV } & \multirow[t]{5}{*}{$\begin{array}{l}\text { Abatacept versus } \\
\text { placebo }\end{array}$} & \multirow[t]{5}{*}{$\begin{array}{l}\text { Corticosteroids + } \\
\text { MMF }\end{array}$} & $\begin{array}{l}\text { Proportion of subjects } \\
\text { achieving complete } \\
\text { renal response at } \\
52 \text { weeks defined as: }\end{array}$ & \multirow[t]{5}{*}{400} & \multirow[t]{5}{*}{98} & \multirow[t]{5}{*}{ International } & \multirow[t]{5}{*}{ July 2017} \\
\hline & & & & & & & $\begin{array}{l}\text { 1. Kidney function: } \\
\text { eGFR normal or no } \\
\text { less than } 85 \% \\
\text { baseline }\end{array}$ & & & & \\
\hline & & & & & & & $\begin{array}{l}\text { 2. Proteinuria: UPC } \\
\text { ratio }<0.5\end{array}$ & & & & \\
\hline & & & & & & & $\begin{array}{l}\text { 3. Urine sediment: no } \\
\text { cellular casts }\end{array}$ & & & & \\
\hline & & & & & & & $\begin{array}{l}\text { 4. Corticosteroid dose: } \\
<11 \mathrm{mg} \text { daily for at } \\
\text { least } 28 \text { days }\end{array}$ & & & & \\
\hline \multirow[t]{6}{*}{ NCT01639339 } & \multirow[t]{5}{*}{$\begin{array}{l}\text { Human Genome } \\
\text { Sciences Inc., a } \\
\text { GSK Company }\end{array}$} & \multirow[t]{5}{*}{ BLISS-LN } & \multirow[t]{5}{*}{$\begin{array}{l}\text { Phase 3, } \\
\text { randomized, } \\
\text { double-blind, } \\
\text { placebo- } \\
\text { controlled }\end{array}$} & \multirow[t]{5}{*}{$\begin{array}{l}\text { III or IV and } \\
\text { coexisting V } \\
\text { if present }\end{array}$} & \multirow[t]{5}{*}{$\begin{array}{l}\text { Belimumab versus } \\
\text { placebo }\end{array}$} & $\begin{array}{l}\text { Corticosteroids }+ \\
\text { CYC for induction } \\
\text { therapy }\end{array}$ & $\begin{array}{l}\text { Number of } \\
\text { participants with } \\
\text { complete renal } \\
\text { response at } \\
104 \text { weeks defined as: }\end{array}$ & \multirow[t]{5}{*}{464} & \multirow[t]{5}{*}{102} & \multirow[t]{5}{*}{ International } & \multirow[t]{5}{*}{$\begin{array}{l}\text { February } \\
2017\end{array}$} \\
\hline & & & & & & $\begin{array}{l}\text {-AZA for } \\
\text { maintenance OR } \\
\text { High-dose } \\
\text { steroids + MMF for } \\
\text { induction therapy }\end{array}$ & $\begin{array}{l}\text { 1. Kidney function: } \\
\text { eGFR no more than } \\
10 \% \text { below pre-flare } \\
\text { value or normal }\end{array}$ & & & & \\
\hline & & & & & & \multirow[t]{3}{*}{$\begin{array}{l}\text {-MMF for } \\
\text { maintenance }\end{array}$} & $\begin{array}{l}\text { 2. Proteinuria: UPC } \\
\text { ratio }<0.5\end{array}$ & & & & \\
\hline & & & & & & & $\begin{array}{l}\text { 3. Urine sediment: } \\
\text { inactive (<5 RBCs/ } \\
\text { WBCs, no casts) }\end{array}$ & & & & \\
\hline & & & & & & & 4. No rescue therapy & & & & \\
\hline & Biogen IDEC & ATLAS & $\begin{array}{l}\text { Randomized, } \\
\text { double-blind, } \\
\text { placebo- } \\
\text { controlled }\end{array}$ & $\begin{array}{l}\text { III or IV and } \\
\text { coexisting V } \\
\text { if present }\end{array}$ & $\begin{array}{l}\text { BllB023 (anti- } \\
\text { TWEAK) at high or } \\
\text { low dose versus } \\
\text { placebo }\end{array}$ & $\begin{array}{l}\text { Corticosteroids + } \\
\text { MMF }\end{array}$ & $\begin{array}{l}\text { Proportion of subjects } \\
\text { who achieve renal } \\
\text { response (complete } \\
\text { or partial) at } 52 \text { weeks }\end{array}$ & 300 & 123 & International & $\begin{array}{l}\text { September } \\
2016\end{array}$ \\
\hline
\end{tabular}


Table 3 An overview of major randomized controlled trials of lupus nephritis treatments currently in progress and their response criteria (Continued)

\begin{tabular}{|c|c|c|c|c|c|c|c|c|c|c|c|}
\hline \multirow[t]{3}{*}{ NCT02141672 } & \multirow[t]{3}{*}{ Aurinia } & \multirow[t]{3}{*}{ AURA-LV } & \multirow[t]{3}{*}{$\begin{array}{l}\text { Randomized, } \\
\text { double-blind, } \\
\text { placebo- } \\
\text { controlled }\end{array}$} & \multirow[t]{3}{*}{$\begin{array}{l}\text { III, IV and/ } \\
\text { or V }\end{array}$} & \multirow[t]{3}{*}{$\begin{array}{l}\text { Voclosporin at } \\
\text { high or low dose } \\
\text { versus placebo }\end{array}$} & \multirow[t]{3}{*}{$\begin{array}{l}\text { Corticosteroids + } \\
\text { MMF }\end{array}$} & $\begin{array}{l}\text { Number of subjects } \\
\text { who achieve } \\
\text { complete remission at } \\
24 \text { weeks defined as: }\end{array}$ & \multirow[t]{3}{*}{222} & \multirow[t]{3}{*}{56} & \multirow[t]{3}{*}{ Inter-national } & \multirow[t]{3}{*}{$\begin{array}{l}\text { December } \\
2016\end{array}$} \\
\hline & & & & & & & $\begin{array}{l}\text { 1. No confirmed } \\
\text { decrease from } \\
\text { baseline in eGFR of } \\
\geq 20 \%\end{array}$ & & & & \\
\hline & & & & & & & $\begin{array}{l}\text { 2. Proteinuria: UPC } \\
\text { ratio }<0.5\end{array}$ & & & & \\
\hline
\end{tabular}

$$
\text { ratio }<0.5
$$

ALLURE, Advancing Leading-Edge Lupus Research; ATLAS, Adjuvant Tamoxifen: AURA-LV, Aurinia Urinary Protein Reduction Active - Lupus with Voclosporin; Longer Against Shorter; AZA, azathioprine; BLISS-LN,

apoptosis; UPC, urine protein-to-creatinine: WBC, white blood cell. 
IVC every 2 weeks for six doses) followed by maintenance with AZA [33,34].

2. The ALLURE (Advancing Leading-Edge Lupus Research) trial also assesses the efficacy of abatacept with background therapy of MMF.

3. The BLISS-LN (Belimumab International Lupus Nephritis Study) trial assesses the efficacy of belimumab-a human monoclonal antibody that inhibits the B-cell survival factor called B-cell activating factor (BAFF; also known as B-lymphocyte stimulator or BLyS) to prevent B-cell survival-with background therapy of Eurolupus IVC or MMF per investigator choice followed by MMF maintenance.

4. The ATLAS (Adjuvant Tamoxifen: Longer Against Shorter) trial assesses the efficacy of BIIB023-a humanized monoclonal antibody that inhibits tumor necrosis factor-related weak inducer of apoptosis (TWEAK) to reduce tissue inflammation-with background therapy of MMF.

All four clinical trials use glucocorticoids as standardof-care therapy. The ACCESS trial and BLISS-LN trial allow IVC remission induction therapy as another option. The ACCESS trial has completed 1-year follow-up data collection on the 134 participants, and the interim data have been published as abstracts [35]. The remaining three clinical trials are led by pharmaceutical companies and are attempting to recruit hundreds of patients from many national and international sites.

Each trial is designed with a primary, composite endpoint of complete renal response; however the criterion used in the endpoint definition varies across studies. Aside from the ACCESS trial, each study includes microscopic review of the urine sediment, namely looking for RBC casts, as a part of the composite endpoint. This may be questioned upon trial completion given the variability in an investigator's ability to reliably and uniformly assess the sediment at each site. While a multi-faceted definition of complete renal response reflects the approach used in clinical care, it is likely difficult to achieve in a research setting, especially in a diverse group of patients recruited from centers around the world.

\section{Surrogate endpoints in chronic kidney disease trials}

Clinical trials should be centered on improving outcomes that matter to patients. In the case of LN, many would agree that the prevention of the need for renal replacement therapy is the clinical endpoint of most concern. However, clinical trials often cannot afford to have as many years of follow-up as the early study by Austin and colleagues. As a result, many clinical trials are designed around surrogate endpoints. The National Institutes of Health defines a surrogate endpoint as a 'biomarker intended to substitute for a clinical endpoint'; that is, a surrogate endpoint is a marker of a treatment effect that may correlate completely with a real clinical endpoint, but this relationship does not always hold true [36]. Surrogate endpoints are selected on the basis of their ability to predict the effect of a treatment on the clinical endpoint of interest $[37,38]$. The FDA allows for initial drug approval based on studies using surrogate endpoints with the caveat that postmarketing surveillance be performed to define long-term effects [39].

The development of novel agents for the treatment of CKD, from any cause, has been plagued by the need to identify appropriate surrogate endpoints. In diabetic nephropathy, the initial approvals for angiotensin-converting enzyme inhibitors and angiotensin receptor blockers relied on a doubling of serum creatinine, ESKD, or death as endpoints. Approval of newer agents to treat diabetic nephropathy, like that of agents to treat LN, has stalled while appropriate surrogate endpoints are defined [40]. Fortunately, the FDA and the American Society of Nephrology recently founded a public and private partnership of all stakeholders that is called the Kidney Health Initiative, which likely will facilitate development of appropriate surrogate endpoints in $\mathrm{LN}$ and other forms of kidney disease [41].

Surrogate endpoints commonly used in clinical trials of CKD include eGFR and proteinuria. Stevens and colleagues [37] published a thorough review of surrogate endpoints in trials of kidney disease several years ago, and we will summarize that review here. By definition, there must be a decrease in GFR for a patient to develop kidney failure, making substantial changes in GFR a reasonable intermediate endpoint for ESKD. However, changes in GFR are sometimes not appreciated in the early stages of kidney disease, and in the case of slowly progressive kidney disease, this may not be a useful endpoint if follow-up is not long enough. eGFR is considered to be a reflection of the number of functioning nephrons; however, glomerular hyperfiltration, glomerular hypertension, kidney perfusion, pregnancy, and medications including but not limited to NSAIDs all influence GFR and may interfere with interpretation [37].

The majority of patients with LN are women, who often have lower muscle mass and thus lower serum creatinine values and may be obese because of steroid exposure. Many clinical trials focus on patients with relatively preserved renal function. The current methods for estimating GFR are less precise with eGFR of more than $60 \mathrm{~mL} / \mathrm{min}$ per $\mathrm{m}^{2}$. The search for a method less affected by weight and muscle mass to more precisely assess change in eGFR would strengthen this criterion as an outcome variable. Recent research assessing GFR employing cystatin $\mathrm{C}$ or iohexol dissipation in young 
diabetic, heart transplant patients or the general population may prove more helpful $[42,43]$.

The power of a slope-based analysis can be jeopardized if the rate of underlying disease progression is not uniform over time or stage of disease. The use of a timeto-event analysis with a composite endpoint made up of objective endpoints such as the need for dialysis, a designated reduction in GFR, and an increase in serum creatinine helps circumvent some of these concerns [37].

Proteinuria has also been used as a surrogate endpoint because it correlates well with GFR and has been implicated in the pathogenesis of CKD. It is an attractive choice because, following an intervention, the change in proteinuria is often earlier and larger than the observed change in GFR. It might be useful therefore in slowly progressive or early stages of disease. The presence of or a change in proteinuria, unlike GFR, is not a mandatory intermediary in the development of kidney failure. As a result, proteinuria must be validated as a surrogate endpoint and this has yet to be done [37]. Complicating the search for surrogate markers are recent reports of patients with LN undergoing protocol repeat renal biopsy at defined time points regardless of clinical status. These have shown a significant discordance between complete or partial remissions defined by the measures above and histologic remissions. These results raise concern that repeat renal biopsy protocols may be required to define surrogate outcome measures for LN [44].

\section{Moving forward}

Just as lupus is a multisystem disease, the design and execution of trials should be multidisciplinary. Input from nephrologists and rheumatologists who routinely care for patients with LN will help ensure that appropriate inclusion/exclusion criteria are chosen and that the selected primary and secondary endpoints are clinically meaningful. Although treatment options in LN have stalled, much can be learned from the trials that have been completed.

Time and again, we have seen success in early studies that was not replicated in multicenter, randomized, placebo-controlled trials. Investigators are charged with demonstrating that the addition of a study drug is more effective than usual care with steroids and current cytotoxic agents with respect to controlling disease, avoiding relapses, or lessening drug toxicity [23]. Given the many side effects associated with steroids, trials typically use and should continue to use a step-down design. This involves starting two agents simultaneously (for example, MMF and prednisone) and then reducing the dose of one agent (in this case, steroids) [23]. A treatment with similar efficacy that allows for steroid reduction would be a favorable option to clinicians and patients. Reduction in steroid dose is also an important endpoint that is not often used in clinical trials of LN.
The endpoints that we, as treating nephrologists and rheumatologists, favor for future clinical trials are composite endpoints that include assessment of GFR and proteinuria. For complete response, we favor proteinuria of less than $0.3 \mathrm{~g}$, regardless of the starting point. The measure of GFR should account for change rather than a static arbitrary value. In patients with or without clinical response, a repeat kidney biopsy would provide definitive evidence of histologic response, including remission, and help validate the chosen surrogate endpoints. Just as a reduction in GFR is an inherent feature of kidney injury, persistent histologic evidence of proliferative nephritis signifies ongoing active kidney injury. GFR and proteinuria do not necessarily change as quickly as one another nor as quickly as the histology in a glomerulus. Therefore, to ensure that follow-up is long enough to permit change, clinical trials should include at least 12 (and, ideally, 24) months of follow-up. Table 4 includes a summary of our suggested endpoints in LN trials.

All study participants must be offered effective treatment such as steroids, anti-malarial agents, angiotensin-

\section{Table 4 Take home points}

1. Kidney disease activity rating scales in systemic lupus erythematosus should include the following:

-A measure of estimated glomerular filtration rate (eGFR)

-Using consensus-based equation

-A measure of proteinuria

-Using 24-hour collection

-Analysis of urine sediment only in conjunction with above

2. Guidelines for future trials of lupus nephritis:

-Complete response should be a composite endpoint of the following:

-Proteinuria of less than $0.3 \mathrm{~g} /$ day

॰ $G F R$ :

-Stable (if more than $60 \mathrm{~mL} / \mathrm{min}$ per $\mathrm{m}^{2}$ at baseline) or

-Improvement of at least 50\% (if less than 60 $\mathrm{mL} / \mathrm{min}$ per $\mathrm{m}^{2}$ at baseline)

- Consider repeat biopsy in patients meeting criteria for response or non-response

-Reduction or discontinuation of glucocorticoids

-Treatment failure should be a composite of the following:

-Need for renal replacement therapy or transplant

-Persistent doubling of serum creatinine

-eGFR decrease by at least 50\%

-Renal flare requiring treatment

-Death

-Design should require 12 to 24 months of follow-up.

-Detailed guidance on steroid dosing should be provided. 
converting enzyme inhibitors or angiotensin receptor blockers, and HMG-CoA reductase inhibitors. Patients entering a trial should receive the same regimen of glucocorticoids with a standard tapering schedule [23]. For example, the abatacept trial did not restrict steroid dosing, and the analysis observed a trend of higher mean prednisone dose among the placebo group, confounding interpretation of the data [26].

Lupus has diverse manifestations, and this is likely due to numerous subtypes of disease. Studying new agents in a more homogeneous patient sample may increase the yield of positive findings. The research into rituximab illustrates this point. The earlier uncontrolled trials were of patients who failed initial therapy with cyclophosphamide or MMF, whereas the LUNAR (Lupus Nephritis Assessment with Rituximab) project enrolled patients receiving initial treatment [31]. It must also be realized, though, that using more inclusion and exclusion criteria must be weighed against the difficulties of patient recruitment.

\section{Conclusions}

The diverse manifestations of SLE pose challenges in the design of clinical trials. To capture disease activity, various disease activity indices have been developed. Thesevary in length and complexity, and many have renal subscales. The renal subscales, particularly in the SLEDAI-2 K (Systemic Lupus Erythematosus Disease Activity Index 2000) and BILAG tools, measure clinically meaningful parameters of kidney involvement, namely eGFR and proteinuria (Table 4). It is important that the best method to define eGFR and proteinuria in LN be identified and then adopted into clinical care and trial design. To advance the knowledge of how to treat LN, well-designed clinical trials informed by prior randomized controlled trials are needed. Clinical trials should have thoughtful inclusion and exclusion criteria, pre-specified dosing parameters for glucocorticoids and other medications, and welldesigned endpoints.

Note: This article is part of the series 'Measuring meaningful change in lupus clinical trials', edited by Matthew Liang and Chan-Bum Choi. Other articles in this series can be found at http://arthritis-research.com/series/trials

\footnotetext{
Abbreviations

ACCESS: Abatacept and Cyclophosphamide Combination: Efficacy and Safety Study; AZA: azathioprine; BILAG: British Isles Lupus Assessment Group; BLISS-LN: Belimumab International Lupus Nephritis Study; CKD: chronic kidney disease; eGFR: estimated glomerular filtration rate; ESKD: end-stage kidney disease; FDA: US Food and Drug Administration; IVC: intravenous cyclophosphamide; LN: lupus nephritis; MMF: mycophenolate mofetil; NSAID: non-steroidal anti-inflammatory drug; RBC: red blood cell; SLE: systemic lupus erythematosus.
}

\section{Competing interests}

The authors declare that they have no competing interests.

\section{Acknowledgments}

We are grateful to Matthew Liang and Chan-Bum Choi for the invitation to write this manuscript. We would like to acknowledge the work of Charles T Owens in gathering references to include in this review. The authors would like to thank the practitioners with whom they work and the patients with lupus nephritis for whom they care.

\section{Author details}

'Division of Nephrology, Department of Medicine, Massachusetts General Hospital, 55 Fruit St., Boston, MA 02114, USA. Division of Nephrology, Department of Medicine, University of North Carolina (UNC) Kidney Center, 7024 Burnett-Womack Building, Campus Box \# 7155, Chapel Hill, NC 27599-7155, USA.

Published online: 28 April 2015

\section{References}

1. Austin 3rd HA, Klippel JH, Balow JE, le Riche NG, Steinberg AD, Plotz PH, et al. Therapy of lupus nephritis. Controlled trial of prednisone and cytotoxic drugs. N Engl J Med. 1986;314:614-9.

2. Rovin BH, Parikh SV, Hebert LA, Chan TM, Mok CC, Ginzler EM, et al. Lupus nephritis: induction therapy in severe lupus nephritis - should MMF be considered the drug of choice? Clin J Am Soc Nephrol. 2013;8:147-53.

3. Tsokos GC. Systemic lupus erythematosus. N Engl J Med. 2011;365:2110-21.

4. Houssiau FA, Lauwerys BR. Current management of lupus nephritis. Best Pract Res Clin Rheumatol. 2013;27:319-28.

5. Ward MM. Changes in the incidence of endstage renal disease due to lupus nephritis in the United States, 1996-2004. J Rheumatol. 2009;36:63-7.

6. Costenbader KH, Desai A, Alarcón GS, Hiraki LT, Shaykevich T, Brookhart MA, et al. Trends in the incidence, demographics, and outcomes of end-stage renal disease due to lupus nephritis in the US from 1995 to 2006. Arthritis Rheum. 2011;63:1681-8.

7. Parikh SV, Nagaraja HN, Hebert L, Rovin BH. Renal flare as a predictor of incident and progressive CKD in patients with lupus nephritis. Clin J Am Soc Nephrol. 2014;9:279-84.

8. Barr RG, Seliger S, Appel GB, Zuniga R, D'Agati V, Salmon J, et al. Prognosis in proliferative lupus nephritis: the role of socio-economic status and race/ethnicity. Nephrol Dial Transplant. 2003;18:2039-46.

9. Cooper GS, Treadwell EL, St Clair EW, Gilkeson GS, Dooley MA. Sociodemographic associations with early disease damage in patients with systemic lupus erythematosus. Arthritis Rheum. 2007;57:993-9.

10. Gibson KL, Gipson DS, Massengill SA, Dooley MA, Primack WA, Ferris MA, et al. Predictors of relapse and end stage kidney disease in proliferative lupus nephritis: focus on children, adolescents, and young adults. Clin J Am Soc Nephrol. 2009;4:1962-7.

11. Obermoser $G$, Pascual $V$. The interferon-alpha signature of systemic lupus erythematosus. Lupus. 2010;19:1012-9.

12. Lech $\mathrm{M}$, Anders $\mathrm{H}-\mathrm{J}$. The pathogenesis of lupus nephritis. J Am Soc Nephrol. 2013;24:1357-66.

13. Kalloo S, Aggarwal N, Mohan P, Radhakrishnan J. Lupus nephritis: treatment of resistant disease. Clin J Am Soc Nephrol. 2013;8:154-61.

14. Balow JE. Renal manifestations of systemic lupus erythematosus. In: Primer on Kidney Diseases. Edited by Greenburg A. Philadelphia, PA: Saunders Elsevier; 2009:208-13.

15. Weening JJ, D'Agati VD, Schwartz MM, Seshan SV, Alpers CE, Appel GB, et al. The classification of glomerulonephritis in systemic lupus erythematosus revisited. J Am Soc Nephrol. 2004;15:241-50.

16. Birmingham DJ, Shidham G, Perna A, Fine DM, Bissell M, Rodby R, et al. Spot $P C$ ratio estimates of 24-hour proteinuria are more unreliable in lupus nephritis than in other forms of chronic glomerular disease. Ann Rheum Dis. 2014;73:475-6.

17. Food and Drug Administration. Guidance for Industry-Systemic Lupus Erythematosus- Developing Medical Products for Treatment. http://google2. fda.gov/search?q=lupus+trials\&client=FDAgov\&site=FDAgov\&l $r=\&$ proxystyle sheet=FDAgov\&requiredfields=-archive\%3AYes\&output=xml_no_ dtd\&getfields $=*$. Accessed 10 March 2014. 
18. Romero-Diaz J, Isenberg D, Ramsey-Goldman R. Measures of adult systemic lupus erythematosus: updated version of British Isles Lupus Assessment Group (BILAG 2004), European Consensus Lupus Activity Measurements (ECLAM), Systemic Lupus Activity Measure, Revised (SLAM-R), Systemic Lupus Activity Questionnaire for Population Studies (SLAQ), Systemic Lupus Erythematosus Disease Activity Index 2000 (SLEDAl-2 K), and Systemic Lupus International Collaborating Clinics/American College of Rheumatology Damage Index (SDI). Arthritis Care Res. 2011;63:S37-46.

19. Bae SC, Koh HK, Chang DK, Kim MH, Park JK, Kim SY. Reliability and validity of systemic lupus activity measure-revised (SLAM-R) for measuring clinical disease activity in systemic lupus erythematosus. Lupus. 2001;10:405-9.

20. Karlson EW, Daltroy LH, Rivest C, Ramsey-Goldman R, Wright EA, Partridge AJ, et al. Validation of a Systemic Lupus Activity Questionnaire (SLAQ) for population studies. Lupus. 2003;12:280-6.

21. Renal Disease Subcommittee of the American College of Rheumatology Ad Hoc Committee on Systemic Lupus Erythematosus Response Criteria. The American College of Rheumatology response criteria for proliferative and membranous renal disease in systemic lupus erythematosus clinical trials. Arthritis Rheum. 2006;54:421-32.

22. Steinberg AD, Decker JL. A double-blind controlled trial comparing cyclophosphamide, azathioprine and placebo in the treatment of lupus glomerulonephritis. Arthritis Rheum. 1974;6:923-37.

23. Liang MH, Corzillius M, Bae SC, Fortin P, Esdaile JM, Abrahamowicz M. A conceptual framework for clinical trials in SLE and other multisystem diseases. Lupus. 1999:8:570-80.

24. Chan TM, Li FK, Tang CS, Wong RW, Fang GX, Ji YL, et al. Efficacy of mycophenolate mofetil in patients with diffuse proliferative lupus nephritis. Hong Kong-Guangzhou Nephrology Study Group. N Engl J Med. 2000;343:1156-62.

25. Appel GB, Contreras G, Dooley MA, Ginzler EM, Isenberg D, Jayne D, et al. Mycophenolate mofetil versus cyclophosphamide for induction treatment of lupus nephritis. J Am Soc Nephrol. 2009;20:1103-12.

26. Furie R, Nicholls K, Cheng T-T, Houssiau F, Burgos-Vargas R, Chen S-L, et al. Efficacy and safety of abatacept in lupus nephritis: a twelve-month, randomized, double-blind study. Arthritis Rheum. 2014;66:379-89.

27. Ginzler EM, Dooley MA, Aranow C, Kim MY, Buyon J, Merrill JT, et al. Mycophenolate mofetil or intravenous cyclophosphamide for lupus nephritis. N Engl J Med. 2005;353:2219-28.

28. Rovin BH, Furie R, Latinis K, Looney RJ, Fervenza FC, Sanchez-Guerrero J, et al. Efficacy and safety of rituximab in patients with active proliferative lupus nephritis: the Lupus Nephritis Assessment with Rituximab study. Arthritis Rheum. 2012;64:1215-26.

29. Contreras G, Pardo V, Leclercq B, Lenz O, Tozman E, O'Nan P, et al. Sequential therapies for proliferative lupus nephritis. N Engl J Med. 2004;350:971-80

30. Dooley MA, Jayne D, Ginzler EM, Isenberg D, Olsen NJ, Wofsy D, et al. Mycophenolate versus azathioprine as maintenance therapy for lupus nephritis. N Engl J Med. 2011;365:1886-95.

31. van Vollenhoven RF. Challenges and opportunities in SLE clincal trials. Curr Opin Rheumatol. 2013;25:606-15.

32. Wofsy D, Hillson JL, Diamond B. Abatacept for lupus nephritis: alternative definitions of complete response support conflicting conclusions. Arthritis Rheum. 2012;64:3660-5.

33. The ACCESS trial group. Treatment of lupus nephritis with abatacept: the abatacept and cyclophosphamide combination efficacy and safety study. Arthritis Rheum. 2014;66:3096-104.

34. Fragoso-Loyo HE, Dooley MA, On behalf of ACCESS Trial Group. Efficacy of the euro-lupus nephritis regimen combined with abatacept vs placebo in a North American lupus nephritis population. Ann Rheum Dis. 2014;73:77-8.

35. Wofsy D, Askanase A, Cagnoli P, Chatham W, Contreras G, Dall'Era M, et al. Treatment of lupus nephritis with abatacept plus low-dose pulse cyclophosphamide followed by azathioprine (the Euro-Lupus regimen). Twenty-four week data from a double-blind controlled trial. Arthritis Rheum. 2013;65:884.

36. Cohn JN. Introduction to surrogate markers. Circulation. 2004;109:IV20-1.

37. Stevens LA, Greene T, Levey AS. Surrogate end points for clinical trials of kidney disease progression. Clin J Am Soc Nephrol. 2006;1:874-84.

38. Liang MH, Simard JF, Costenbader K, Dore BT, Ward M, Fortin PR, et al. Methodologic issues in the validation of putative biomarkers and surrogate endpoints in treatment evaluation for systemic lupus erythematosus. Endocr Metab Immune Disord Drug Targets. 2009;9:108-12.
39. Code of Federal Regulations, Title 21, Volume 7. Food and Drug Administration, Department of Health and Human Services. 2014. http:// www.accessdata.fda.gov/scripts/cdrh/cfdocs/cfffr/CFRSearch.cfm?fr=601.41. Accessed 10 March 2014

40. McKinney TD. Influence of decisions related to business and regulatory considerations on therapeutic development for kidney diseases. Clin J Am Soc Nephrol. 2012;7:1195-9.

41. Archdeacon P, Shaffer RN, Winkelmayer WC, Falk RJ, Roy-Chaudhury P. Fostering innovation, advancing patient safety: the kidney health initiative. Clin J Am Soc Nephrol. 2013;8:1609-17.

42. Woo K, Choi J, Kim B, Kim JC, Han J. Clinical usefulness of serum cystatin C as a marker of renal function. Diabetes Metab J. 2014;38:278-84

43. Levey AS, Inker LA, Coresh J. GFR estimation: from physiology to public health. Am J Kidney Dis. 2014;63:820-34.

44. Zickert A, Sundelin B, Svenungsson E, Gunnarsson I. Role of early repeated renal biopsies in lupus nephritis. Lupus Sci Med. 2014;1, e000018.

45. Gladman DD, Ibanez D, Urowitz MB. Systemic lupus erythematosus disease activity index 2000. J Rheumatol. 2002;29:288-91.

46. Gordon C, Sutcliffe N, Skan J, Stoll T, Isenberg DA. Definition and treatment of lupus flares measured by the BILAG index. Rheumatology. 2003;42:1372-9.

47. Gladman DD. The development and initial validation of the Systemic Lupus Erythematosus International Collaborating Clinics/American College of Rheumatology Damage Index for systemic lupus erythematosus. Arthritis Rheum. 1996:39:363.

48. Houssiau FA, Vasconcelos C, D'Cruz D, Sebastiani GD, de Ramon GE. Danieli, et al. Immunosuppressive therapy in lupus nephritis: the Euro-Lupus Nephritis Trial, a randomized trial of low-dose versus high-dose intravenous cyclophosphamide. Arthritis Rheum. 2002:46:2121-31.

49. Houssiau FA, Vasconcelos C, D'Cruz D, Sebastiani GD, de Ramon GE, Danieli, et al. The 10-year follow-up data of the Euro-Lupus Nephritis Trial comparing low-dose and high-dose intravenous cyclophosphamide. Ann Rheum Dis. 2010;69:61-4. 